\title{
O PAPEL DO TRIBUNAL DE CONTAS DA UNIÃO NO CICLO DE POLÍTICAS PÚBLICAS UM ESTUDO SOBRE O PROGRAMA UNIVERSIDADE PARA TODOS (PROUNI)
}

In journal.nuped.com.br/index.php/congressoibda/article/view/leoni2021

\section{Autores}

Fernanda Leoni Universidade Federal do ABC https://orcid.org/0000-000263ㅜㄴ-7ㅁ37-

\section{Palavras-chave:}

Ciclo de políticas públicas, Tribunal de Contas da União, TCU, Controle, ProUni

\section{Resumo}

Acompanhando o movimento de fortalecimento da democracia no país, o Tribunal de Contas da União, no desempenho de sua função de controle, passou a ser requisitado no fechamento do ciclo de representação, o que trouxe ao órgão maior envolvimento com a temática das políticas públicas. Nesse sentido, o objetivo do trabalho é compreender como se dá o envolvimento do Tribunal de Contas no ciclo de políticas públicas, a partir do controle que exerce sobre programas públicos. Assim, focou-se na atividade do TCU (esfera federal), elegendo-se a educação superior como macroárea e o Programa Universidade para todos (ProUni) como política pública específica ao estudo de caso, a partir da análise de acórdãos proferidos entre os anos de 2008 a 2013 em auditoria operacional sobre o programa. Nestes acórdãos, foram avaliados os tipos de recomendações e determinações realizadas pelo TCU nas etapas de formação da agenda, implementação e avaliação da política pública. Os dados obtidos mostram que temas com impacto para a formação da agenda pública foram tratados pelo TCU em caráter de recomendação, com indicações de melhorias, mas sem intervenção na discricionariedade do gestor. Na fase de implementação, os comandos do TCU adotaram, majoritariamente, caráter de determinação, impondo medidas corretivas. Por fim, na fase de avaliação, o TCU optou por monitorar o cumprimento de recomendações e determinações anteriores, mas sem aplicação de sanções aos gestores. Tem-se que o Tribunal mediu precisamente o nível de intervenção em cada fase, mostrando-se mais autorrestritivo nas etapas envolvidas com o poder discricionário do gestor, e mais proativo nas determinações voltadas ao cumprimento da lei. Conclui-se, assim, que o TCU, como um novo ator em políticas públicas, tem condições de se envolver ativamente com a temática, trazendo contribuições relevantes ao campo.

\section{Downloads}

Não há dados estatísticos. 


\section{Referências}

ALMEIDA, Wilson Mesquita de. Ampliação do acesso ao ensino superior privado lucrativo brasileiro: um estudo sociológico com bolsistas do ProUni na cidade de São Paulo. 2012. 294f. Tese (Doutorado em Sociologia). Faculdade de Filosofia, Letras e Ciências Humanas, Universidade de São Paulo, São Paulo.

BRASIL, Tribunal de Contas da União. Referencial para avaliação de governança em políticas públicas. Brasília: TCU, 2014.

DECOMAIN, Pedro Roberto. Tribunais de contas no Brasil. São Paulo: Dialética, 2006.

GUALAZZI, Eduardo Lobo Botelho. Regime jurídico dos tribunais de contas. São Paulo: Revista dos Tribunais, 1992.

IOCKEN, Sabrina Nunes. Políticas públicas: o controle do tribunal de contas. Florianópolis: Conceito Editorial. 2014.

NOBREGA, Marcos. Os tribunais de contas e o controle dos programas sociais. Belo Horizonte: Fórum, 2011.

Como citar na referência:

LEONI, F. O PAPEL DO TRIBUNAL DE CONTAS DA UNIÃO NO CICLO DE POLÍTICAS PÚBLICAS UM ESTUDO SOBRE O PROGRAMA UNIVERSIDADE PARA TODOS (PROUNI). In: SAIKALI, Lucas Bossoni; ANDRADE, Giulia De Rossi; DOTTA, Alexandre Godoy. (Orgs.). Direito Administrativo e Inovação: Crise e Solução - Caderno dos Resumos das Comunicações Científicas do XXXV Congresso Brasileiro de Direito Administrativo. ISBN 9786599527821, Curitiba: GRD Editora, 2021., p. 71-72, 2021. Disponível em:

https://journal.nuped.com.br/index.php/congressoibda/article/view/leoni2021. Acesso em: 14 out. 2021. 


\section{Direito Administrativo \&}

Inovação: crisee solução

\section{Caderno dos Resumos das} Comunicações Científicas

\section{ibda}

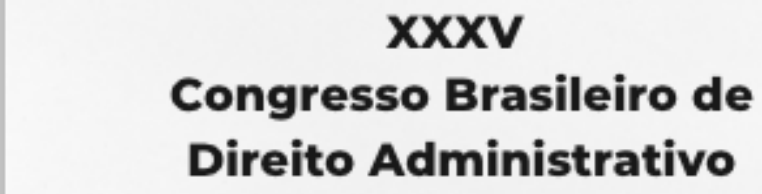

Downloads

DOI:10.5281/zenodo.55714으

\section{Publicado}

14.10 .2021

\section{Licença}

Copyright (c) 2021 Fernanda Leoni

\section{(c) (7)}

Este trabalho está licenciado sob uma licença Creative Commons Attribution 4.0 International License. 